\title{
Polarisasi etnis dan potensi konflik dalam kebijakan pencetakan sawah baru: Sebuah kajian kepustakaan
}

\section{Ethnical polarization and potential conflicts in the new rice field plan policy: A literature study}

\author{
Dwi Wulan Pujiriyani
}

Sekolah Tinggi Pertanahan Nasional

Korespondensi penulis: lucia_wulan@yahoo.com

\begin{abstract}
This study aims to analyse the implementation of new rice field plan policies in Indonesia and their impacts on population and ethnic composition in new rice field locations. This research is conducted by applying a literature review method. It shows that the implementation of the policies had two major implications. Firstly, it creates assimilation opportunities through collaboration between ethnic migrants and local ethnic groups to work on or to cultivate new rice fields. Secondly, the great flows of transmigrants that move to the new rice field locations trigger ethnic polarization, which is prone to cause inter-ethnic conflict. In the future, potential problems associated with the provision of new rice fields are the risk of having aging population. The aging population indicates a decrease in productive labor that may also affect on decreasing attractiveness of the rice fields to the younger generation. This situation can lead to the reinvolvement of older generation in managing the new rice fields. However, it can raise a new concern on their ability to improve the rice fields 'productivity or, even worse, the new rice fields might be neglected or be sold.
\end{abstract}

Keywords: ethnicity, culture, new rice field plan policies, transmigrant

\begin{abstract}
ABSTRAK
Kajian ini bertujuan untuk menganalisis implementasi kebijakan pencetakan sawah baru di Indonesia serta dampaknya pada populasi dan komposisi etnis di lokasi-lokasi cetak sawah. Penelitian ini dilakukan melalui metode kajian kepustakaan. Hasil penelitian menunjukkan bahwa implementasi kebijakan pencetakan sawah baru berimplikasi pada dua hal. Pertama, implementasi kebijakan berdampak menciptakan peluang asimilasi melalui kerjasama antara etnis pendatang (transmigran) dan etnis lokal dalam mengerjakan atau mengolah lahan cetak sawah baru. Kedua, gelombang transmigran yang didatangkan ke lokasi-lokasi cetak sawah baru memicu terjadinya polarisasi etnis yang rentan menimbulkan benih-benih konflik etnis. Potensi persoalan ke depan yang akan dihadapi ketika lahan-lahan cetak sawah sudah tersedia adalah prediksi akan terjadinya penuaan populasi. Penuaan populasi menandakan berkurangnya tenaga produktif yang artinya jikalau sawah-sawah tersebut akan ada, sudah tidak menarik bagi anak muda pun. Pada akhirnya persawahan kembali akan dikelola oleh generasigenerasi tua. Pengelolaan sawah oleh generasi tua ini dikhawatirkan tidak akan mampu meningkatkan produktifitas pertanian dan kembali lagi sawah-sawah akan terlantar atau bahkan mungkin dijual.
\end{abstract}

Kata kunci: etnisitas, budaya, kebijakan pencetakan sawah baru, transmigran

\section{PENDAHULUAN}

Etnisitas dalam studi demografi berkaitan dengan bagaimana seseorang mengidentifikasi dirinya sendiri dan bagaimana mereka dipandang oleh peer group mereka. Mengacu pada studi etnodemografi yang dilakukan Ananta dkk. (2015, hlm. 2), saat ini Indonesia memiliki lebih dari 600 kelompok etnis. Dengan variasi etnis yang ada, terdapat dua kemungkinan yang bisa terjadi yaitu proses asimilasi budaya atau penguatan identitas (polarisasi etnis). Asimilasi budaya merupakan sebuah proses yang konstruktif karena menjembatani dan meminimalisasi kemungkinan terjadinya gesekan di antara berbagai kelompok etnis yang ada. Asimilasi sangat dimungkinkan dengan semakin mobile-nya masyarakat Indonesia yang didukung oleh semakin membaiknya teknologi dan transportasi yang menghubungkan 
mereka yang berasal dari dalam maupun dari luar Indonesia. Sebaliknya, penguatan identitas (polarisasi etnis) sangat rentan memicu terjadinya konflik (Alesina \& La Ferrara, 2005).

Mengacu pada Esteban dan Ray (1994), polarisasi etnis terjadi ketika terdapat dua atau beberapa kelompok etnis yang berbeda dengan kuantitas yang hampir seimbang. Situasi ini menciptakan antagonisme di antara kedua kelompok etnis tersebut. Sebuah negara yang memiliki sejumlah kelompok kecil lebih stabil dibanding negara yang memiliki dua kelompok dengan jumlah yang relatif seimbang. Polarisasi berkaitan dengan kerangka identifikasi atau alienasi. Indeks polarisasi menggambarkan identifikasi individuindividu dalam kelompok etnis mereka, melalui penegasan perbedaan yang mereka miliki dengan kelompok etnis yang lain. Polarisasi memicu perasaan ingroup feeling yang sangat kuat sehingga cenderung melihat kelompok etnis yang lain sebagai kompetitor.

Sebagai konsekuensi dari keberagaman komposisi etnis di Indonesia, asimilasi dan polarisasi menggambarkan bahwa etnis merupakan bagian penting yang harus dipertimbangkan oleh pemerintah dalam memilih dan mengimplementasikan kebijakan pembangunan. Salah satu kebijakan pembangunan yang dibahas terkait dengan komposisi dan populasi etnis di Indonesia adalah kebijakan pencetakan sawah baru. Kebijakan cetak sawah baru bukanlah sebuah kebijakan yang benar-benar baru karena sudah dirintis sejak era Presiden Soeharto sebagaimana termuat dalam Keputusan Presiden RI No. 54 Tahun 1980 tentang Kebijakan Mengenai Pencetakan Sawah. Kebijakan ini kemudian dilanjutkan pada era Presiden Susilo Bambang Yudhoyono hingga era Presiden Joko Widodo. Sejuta hektare lahan gambut di Kalimantan dan Merauke Integrated Food and Energy Estate (MIFEE) merupakan dua contoh varian kebijakan pencetakan sawah baru (Nugraha, 2016; Haryanti, 2020; Putri, 2020). Pencetakan sawah adalah kegiatan mengubah fungsi area tanah bukan sawah menjadi sawah irigasi. Pencetakan sawah dilakukan di daerah dalam kawasan jaringan irigasi yang dibangun oleh pemerintah.

Pencetakan sawah merupakan kebijakan yang dilakukan pemerintah untuk memenuhi kebutuh- an pangan terutama beras dalam rangka usaha swasembada pangan dan meningkatkan pendapatan petani (Tim Analisis BPK Biro Analisa APBN \& Sugema, 2013). Pada kenyataannya, Indonesia sebagai negara yang memiliki penduduk lebih dari 250 juta jiwa memang memiliki tanggung jawab untuk menyediakan jumlah pangan yang cukup bagi seluruh penduduknya. Dalam upaya memenuhi kebutuhan pangan nasional inilah, kebijakan pencetakan sawah baru dimunculkan dalam rangka ekstensifikasi pertanian melalui pencetakan sawah baru. Kebijakan ini dipandang perlu dilakukan untuk mencegah terjadinya penurunan produksi hasil pertanian dan untuk memenuhi kebutuhan pangan (Elfianto, 2013, 7).

Kementerian Pertanian Republik Indonesia melalui Direktorat Perluasan dan Optimasi Lahan, Ditjen Prasarana dan Sarana Pertanian (PSP) melaksanakan pembukaan lahan pertanian di berbagai daerah. Perluasan area tanaman pangan melalui pencetakan sawah baru diarahkan agar mampu menumbuhkan sentra pangan baru di berbagai wilayah yang dikelola secara ekonomis. Hal ini diperlukan untuk memperkuat cadangan pangan nasional, menciptakan lapangan kerja, dan, pada akhirnya, menempatkan petani dan pertanian rakyat menjadi sokoguru perekonomian Indonesia. Pencetakan sawah baru diarahkan untuk menjadi penyeimbang laju konversi lahan sawah yang mencapai 100.000 hektare per tahun. Proyek cetak sawah ditujukan bagi kompensasi atas alih fungsi lahan pertanian di Jawa yang berlangsung masif (Larastiti, 2018).

Tulisan ini membahas mengenai polarisasi etnis dan potensi konflik yang rentan muncul dalam konteks keberagaman komposisi etnis yang ada di Indonesia. Hal ini berkaitan dengan lokasi-lokasi pencetakan sawah baru yang memang lebih banyak diorientasikan di luar Jawa yang tidak semua masyarakatnya memiliki kultur persawahan yang sama dengan kultur persawahan di Jawa. Penelusuran melalui kajian kepustakaan menunjukkan bahwa kebijakan pencetakan sawah memiliki catatan tentang persinggungan antara masyarakat setempat dan masyarakat pendatang. Persinggungan ini pada kenyataannya tidak sepenuhnya berjalan dengan baik. Proyek Lahan Gambut (PLG) pada masa orde Baru merupakan contoh konkret terjadinya konflik etnis antara 
orang Dayak dan masyarakat transmigran. Narasi pembangunan lahan produktif di Kalimantan ini telah memobilisasi petani dan pekerja dari Jawa dan memberi mereka sertifikat tanah dan perumahan gratis. Kondisi ini pada akhirnya menimbulkan kecemburuan sosial dari penduduk setempat (orang Dayak) yang menganggap transmigran diberikan perlakuan yang lebih baik. Penduduk setempat yang telah tinggal sekian puluh tahun justru tidak diberikan sertifikat tanah dan perumahan gratis seperti yang diberikan kepada pendatang (Miranda \& Adventa, 2020). Persinggungan antaretnis ini menjadi isu penting dalam konteks kebijakan pencetakan sawah baru. Isu ini penting untuk dielaborasi lebih mendalam di tengah kajian mengenai pencetakan sawah baru yang justru lebih fokus pada aspek teknis seperti evaluasi tanah (Prasetyo, 2006) dan aspek ketersediaan infrastruktur pengairan (Thoriq \& Sampurna, 2016).

Ketika terjadi persinggungan etnis, persoalan yang kemudian muncul adalah perbedaan nilai mengenai 'siapa yang membutuhkan sawah' dan 'pengiriman tenaga untuk mengolah lahan-lahan sawah yang telah dicetak'. Persinggungan etnis rentan muncul karena salah satu desain yang akan melengkapi implementasi kebijakan pencetakan sawah baru adalah pengiriman transmigran baru dari Jawa ke lokasi-lokasi pencetakan sawah. Pertanyaan yang dijawab melalui tulisan ini yaitu: Bagaimana implementasi kebijakan pencetakan sawah baru di Indonesia? Apa saja dampak yang dimunculkan khususnya berkaitan dengan populasi dan komposisi etnis di lokasi-lokasi cetak sawah? Bagaimana proyeksi ke depan yang dimungkinkan terjadi dari pembelajaran yang diperoleh?

\section{METODOLOGI}

Penelitian ini merupakan penelitian desk study tentang kebijakan (study of policies). Penelitian tentang kebijakan dalam penelitian ini difokuskan pada penelitian tentang 'kinerja' kebijakan yaitu penelitian yang diarahkan untuk memeriksa dampak kebijakan terhadap masyarakat/publik atau yang disebut sebagai target kebijakan. Target kebijakan dalam konteks ini adalah masyarakat yang menjadi calon pengolah lahan sawah baru.
Penelusuran kepustakaan untuk sumber data dalam penelitian ini dilakukan melalui e-research atau kajian kepustakaan yang dilakukan dengan memanfaatkan sumber-sumber yang bisa diakses secara daring. Kajian kepustakaan yang digunakan dalam penelitian ini adalah kajian kepustakaan dengan pendekatan integratif. Melalui pendekatan integratif, alur kerja penelitian ini dilakukan dengan memilih sumber-sumber sekunder yang secara khusus mampu memberikan dukungan fakta empirik berkaitan dengan praktik dan dampak kebijakan pencetakan sawah baru yang telah dan sedang dilakukan di Indonesia.

Jenis kepustakaan daring yang digunakan sebagai sumber data meliputi surat kabar elektronik, laporan penelitian yang diunggah dalam situs web, dan jurnal yang bisa ditelusuri secara daring mengenai implementasi kebijakan sawah baru. Sebagaimana disampaikan Snyder (2019), kajian kepustakaan memberikan dasar untuk mengembangkan pengetahuan dan memandu praktik kebijakan dengan memberikan bukti dari dampak-dampak kebijakan yang diimplementasikan. Melalui kajian ini, implementasi kebijakan pencetakan sawah baru dapat dilihat melalui dampaknya pada para petani yang menjadi pengolah lahan sawah baru. Penelusuran kepustakaan daring dilakukan dengan menggunakan kata kunci utama yaitu 'pencetakan sawah baru dan konflik etnis'. Rentang waktu penelusuran untuk sumber kepustakaan adalah pustaka yang diakses secara daring pada periode tahun 2016 sampai dengan tahun 2021 dengan jumlah kepustakaan spesifik sebanyak 30 sumber pustaka.

Analisis data dalam penelitian ini dilakukan secara kualitatif. Evaluasi pelaksanaan kebijakan sawah baru yang sudah ditemukan dari hasil penelusuran secara daring dikategorisasikan menjadi dua yaitu 'penerimaan kebijakan dari kelompok target/penerima manfaat' dan 'penolakan kebijakan dari kelompok target/penerima manfaat'. Melalui dua kategorisasi ini, kajian ini melakukan klasifikasi lebih lanjut terkait problem-problem etnis yang muncul di seputar implementasi kebijakan pencetakan sawah baru. Kategorisasi inilah yang menjadi pijakan analisis mengenai potensi konflik dari kebijakan pencetakan sawah baru. 


\section{PENCETAKAN SAWAH BARU DI INDONESIA}

Sawah merupakan salah satu penopang penting dalam masyarakat agraris sebagaimana dapat dilihat dalam kutipan berikut:

Kehidupan di negeri agraris dipengaruhi kesanggupan bertani. Hidup dijelaskan melalui sawah. Sawah adalah "Permata Benoea Timoer". Sawah adalah bukti peradaban di Timur terus berkembang, sejak ribuan tahun silam. Sawah mengartikan nafas hidup belum selesai, keringat tak pernah mengering, dan kerja menjadi ejawantah ibadah (Mawardi, 2015)

Pencetakan sawah merupakan salah satu kebijakan yang lahir dari sebuah optimisme kemakmuran Indonesia sebagai negara agraris. Perluasan areal tanaman pangan melalui pencetakan sawah barub diarahkan agar mampu menumbuhkan sentra pangan baru di berbagai wilayah yang dikelola secara ekonomis sehingga dapat memperkuat cadangan pangan nasional, dapat menciptakan lapangan kerja, dan dapat menempatkan petani dan pertanian rakyat menjadi sokoguru perekonomian Indonesia.

Kebutuhan perluasan lahan melalui pencetakan sawah baru diperlukan untuk memastikan bahan pangan dapat diproduksi dalam jumlah yang mencukupi. Target dari pencetakan sawah baru adalah wilayah-wilayah di Indonesia yang masih memiliki lahan yang luas, seperti Sumatra, Kalimantan, Sulawesi, dan Papua. Perluasan sawah merupakan investasi publik yang juga dilakukan dengan melibatkan tentara melalui kegiatan Tentara Mendukung Ketahanan Pangan (TMKP) yang diharapkan mampu mengakselerasi tercapainya target perluasan sawah dalam waktu yang cepat, tepat dan berkualitas (Elfianto, 2013). Kegiatan pencetakan sawah dianggap prospektif karena masih cukup luasnya potensi lahan yang terdapat di luar Pulau Jawa, terutama di Pulau Sumatra, Kalimantan, Sulawesi, dan Papua. Dalam hal ini, pemerintah Indonesia meyakini masih memiliki 23 juta hektare lahan yang dapat dialihkan menjadi lahan pertanian baru untuk menambah lahan pertanian yang saat ini hanya sekitar 7,3 juta hektare. Dalam RPJMN 2015-2019 (Nawacita), pencetakan sawah baru merupakan program prioritas pertama dengan target total 1 juta hektare lahan. Pada tahun 2015, pencetakan sawah baru ditargetkan sejumlah 200 ribu hektare dan akan dilaksanakan di 11 dari 15 provinsi sentra produksi padi dan 17 wilayah di luar provinsi sentra. Apabila berhasil menambah lahan pertanian, Indonesia dipastikan mampu menghindari ancaman krisis pangan yang diperkirakan terjadi pada tahun 2035. Selama 30 tahun terakhir, penambahan lahan pertanian di Indonesia sangat kecil (kurang dari 3\%). Hal ini sangat berbeda dengan perkebunan yang dalam periode sama mengalami penambahan lahan hingga $144 \%$.

Ekstensifikasi lahan sawah dilakukan oleh Direktorat Jenderal Pengolahan Lahan dan Air (PLA) yang dibentuk melalui Peraturan Presiden No. 10 Tahun 2005 dan ditindaklanjuti dengan Peraturan Menteri Pertanian No. 299/ Kpts/OT.140/7/2005. Fokus ekstensifikasi lahan adalah daerah-daerah di luar Jawa. Tahap pertama pencetakan sawah dilakukan pada tahun 2006-2010 dan periode kedua dilakukan pada tahun 2010-2014. Pada periode kedua, pencetakan sawah ditangani oleh Direktorat Jenderal Prasarana dan Sarana Pertanian. Pada tahun 2006-2010, sawah baru yang berhasil dicetak seluas 69.102 hektare. Pada tahun 2011 sawah baru yang berhasil dicetak seluas 62.100 hektare, diikuti pada tahun 2012 seluas 100.000 hektare, tahun 2013 seluas 65.000 hektare, dan tahun 2014 seluas 24.000 hektare.

Tabel 1. Perkembangan Volume Kegiatan Perluasan Sawah, 2006-2014

\begin{tabular}{llc}
\hline Tahun & \multicolumn{1}{c}{ Keterangan } & Luas (Ha) \\
\hline $2006-$ & Perluasan sawah Direktorat & 69.102 \\
2010 & Jendral Pengelola Lahan dan & \\
& Air (PLA) \\
\hline 2011 & Perluasan sawah Direktorat & 62.100 \\
& Jendral Sarana dan Prasarana \\
& Pertanian (PSP) \\
\hline 2012 & Perluasan sawah Direktorat & 100.000 \\
& Jendral Sarana dan Prasarana \\
\hline $2013-$ & Pertanian (PSP) \\
2014 & Rencana perluasan sawah & 200.000 \\
& Prasarana Pertanian (PSP) \\
\hline
\end{tabular}

Sumber: Elfianto (2013) 
Pada tahun 2015, sawah baru yang berhasil dicetak seluas 20.070 hektare, tahun 2016 seluas 132.129 hektare, tahun 2017 seluas 60.243 hektare, tahun 2018 seluas 9.472 hektare dan tahun 2019 seluas 6.000 hektare. Lokasi-lokasi pencetakan sawah ini tersebar di beberapa kabupaten di berbagai wilayah Indonesia antara lain: Aceh (Aceh Barat, Aceh Barat Daya, Aceh Jaya, Pidie, Aceh Singkil, Subulussalam), Jambi (Sungai Penuh, Tanjung Jabung Timur, Tebo), Lampung (Way Kanan, Tulang Bawang, Mesuji, Mesuji Timur), Sumatera Barat (Darmasraya, Pesisir Selatan), Sumatera Selatan (Ogan Komering Ulu, Musi Banyuasin), Banten (Lebak), Kalimantan Barat (Kanyong Utara, Pontianak, Sekadau), Kalimantan Timur (Malinau, Tana Tidung, Tanjung Palas Utara), Kalimantan Selatan (Kota Baru), Kalimantan Tengah (Kota Waringin), Bengkulu (Bengkulu Tengah, Bengkulu Utara, Curup Selatan, Bengkulu Tengah, Rejang Lebong), Sulawesi Barat (Mamuju Utara, Mejene, Mamuju), Sulawesi Tengah (Morowali, Parigi Moutong), Sulawesi Tenggara (Konawe Utara), Nusa Tenggara Barat (Lombok Utara, Lombok Timur), Gorontalo (Gorontalo Utara), Maluku Utara (Halmahera Selatan, Halmahera Tengah, Halmahera Utara, Kepulauan Sula, Morotai, Tidore Kepulauan), Nusa Tenggara Timur (Belu, Timor Tengah Selatan), Papua (Papua Barat-Kaimana, Fak-Fak).

Pencetakan sawah baru disebutkan telah berhasil meningkatkan perekonomian masyarakat (Suandi dkk., 2013; Mampioper, 2008; Husain, 2018; Ikwanto, 2019; Nurhana dkk., 2019; Sastrawan dkk., 2019). Pencetakan sawah baru memberikan beberapa manfaat kepada petani, yaitu menambah luas lahan sawah, meningkatkan produksi, membuka lapangan kerja, menambah intensitas tanaman, dan menambah keragaman tanaman yang diusahakan. Salah satunya dapat dilihat dari sikap positif petani terhadap program pencetakan sawah baru yang dijumpai pada petani di Kelurahan Simpang, Kecamatan Berbak, Kabupaten Jabung Timur, Provinsi Jambi sebagaimana ditunjukkan dalam penelitian Suandi dkk. (2013). Bagi petani, program pencetakan sawah baru dinilai sangat membantu dalam perluasan lahan petani dan pemanfaatan lahan tidur petani. Hal serupa juga ditemukan dalam penelitian Nurhana dkk. (2019) di Desa Botto, Kecamatan Pitu Riase, Kabupaten Sidrap, Provinsi Sulawesi Selatan. Program pencetakan sawah baru di desa ini dinilai mampu memberikan perubahan sosial ekonomi kepada masyarakat berupa penggunaan tenaga kerja, peningkatan interaksi sesama petani, perubahan status mata pencaharian, dan peningkatan pendapatan.

Melalui pencetakan sawah, masyarakat memiliki peluang untuk bisa mengubah lahanlahan yang semula tidak produktif menjadi lahan produktif yang memberikan peningkatan pendapatan. Salah satu perubahan yang dirasakan masyarakat dapat dicermati dalam testimoni Gambar 1.

Meskipun di satu sisi dikatakan mampu menjadi sebuah kebijakan yang efektif untuk bisa meningkatkan perekonomian masyarakat, kebijakan pencetakan sawah baru juga banyak mendapatkan kritik. Merujuk pada Ramadani dkk. (2019), pencetakan sawah bisa dikatakan berhasil bukan semata mencetak hamparan sawah secara fisik tetapi lebih kepada menciptakan masyarakat tani yang mengerti terhadap tanahnya. Konsep mengerti terhadap tanah inilah yang masih meninggalkan persoalan dalam program kebijakan pencetakan sawah baru. Sebagaimana ditunjukkan dalam penelitian Mustapa dkk. (2019), program cetak sawah yang dilaksanakan di luar Pulau Jawa terkendala oleh faktor sosial budaya. Sebagian peserta cetak sawah tidak terbiasa dengan pertanian intensif seperti sawah sehingga sebagian lahan sawah yang ada tidak dimanfaatkan ataupun dimanfaatkan tidak optimal. Hal ini salah satunya dapat dilihat dari banyaknya petani lahan cetak sawah baru di Kabupaten Bangka yang membiarkan lahan mereka kosong. Petani memilih untuk melakukan kegiatan pertanian lain atau kegiatan penambangan daripada budidaya padi. Rata-rata petani tidak tertarik mengelola sawah (Mustikarini \& Santi, 2020).

Hal serupa ternyata juga terjadi di Nagari Siguhung, Kecamatan Lubuk Basung, Kabupaten Agam, Sumatera Barat. Pemanfaatan program pencetakan sawah baru di Nagari Siguhung ternyata masih rendah. Hal ini terlihat dari kenyataan bahwa tidak semua sawah yang telah dicetak tersebut dimanfaatkan petani. Rendahnya 


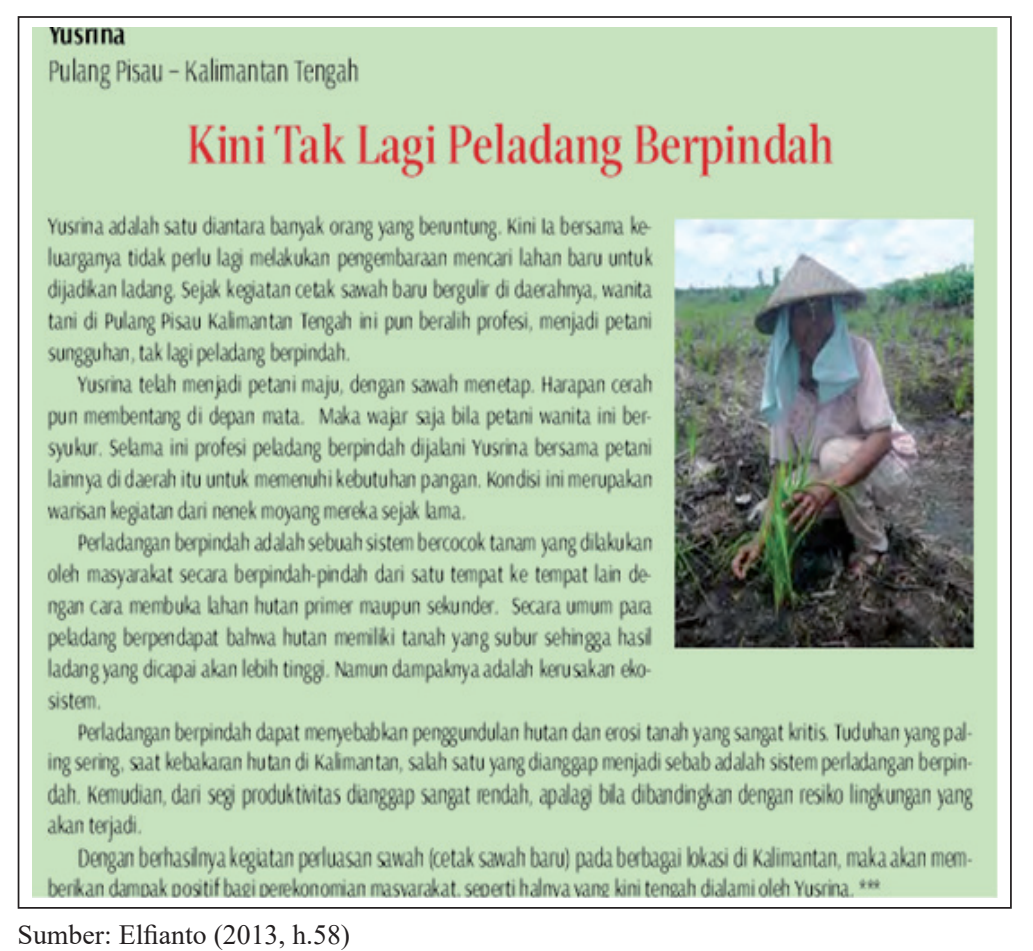

Gambar 1. Testimoni Petani Lahan Cetak Sawah Baru

tingkat pemanfaatan ini disebabkan oleh dua faktor yaitu faktor teknis dan nonteknis. Faktor teknis bersumber dari ketidaktepatan dalam penentuan calon lokasi dan calon penerima program (Astuti \& Kurniawan, 2017). Catatan lain mengenai pencetakan sawah baru juga dapat ditemukan di Kabupaten Sanggau. Pencetakan sawah baru di wilayah ini ternyata memerlukan biaya sosial yang cukup tinggi. Sebagai contoh, perlunya biaya untuk upacara adat sebelum membuka dan mencetak lahan. Masyarakat yang mendukung perluasan sawah umumnya berasal dari petani yang sudah terbiasa menanam padi dan memahami tentang budidaya padi. Sementara itu, mereka dengan pemahaman budidaya padi yang rendah cenderung tidak mendukung kegiatan perluasan sawah (Darwis, 2019).

Beberapa evaluasi dan kritik yang terjadi pada pelaksanaan kebijakan ini menunjukkan bahwa problem penyediaan pangan yang diharapkan belum terpecahkan melalui kebijakan ini. Di samping membutuhkan investasi yang besar, pembangunan sawah baru di luar Jawa, juga memerlukan petani yang andal. Ketidaksesuaian penempatan kegiatan perluasan sawah pada kawasan yang secara agroekologis tidak sesuai untuk tanaman padi, tidak tersedianya jaringan pengairan baik irigasi maupun drainase, ego sektoral yang menyebabkan tidak terjalinnya koordinasi lintas sektor secara baik, serta informasi ketersediaan lahan yang bebas dari masalah status dan sengketa kepemilikan dan pengelolaan merupakan beberapa hal yang disebutkan sebagai penyebab kegagalan kebijakan ini. Selain itu, kesenjangan kultur agraris akibat perbedaan kultur pertanian di Jawa dan luar Jawa juga menyebabkan kegiatan bersawah kurang begitu diminati, seperti salah satunya dapat dicermati dalam kutipan berikut ini:

"Sekarang ini, baik di Karo Hilir (Karo Jahe) maupun di Dataran Tinggi Karo (Karo Gugung), warga Suku Karo mulai berpaling dari padi sawah (page sabah) ke padi ladang (page tuhur). Khusus di Dataran Tinggi Karo, padi ladang biasanya dikombinasikan dengan cabai merah. Ketika bunga padi mulai berbulir (rumpah), mereka menanam cabai merah di ladang yang sama. Ketika padi sampai pada tahap panen, cabai mulai berbunga. Berbeda dengan padi sawah yang menuntut pemakaian pupuk dan obat-obatan kimia, padi ladang ini bebas dari penggunaan pupuk dan obatan kimia alias organik. Menurut orang-orang yang menanam padi ladang, ketahanan padi ladang jauh lebih lama daripada padi sawah. "Memakan nasi dari padi ladang untuk sarapan pagi bisa bertahan hingga Pkl. 13.00 
siang, sedangkan padi sawah hanya sampai Pkl. 11.00," kata seorang petani padi ladang di Desa Lingga (Kecamatan Simpang Empat, Kabupaten Karo). Beberapa warga Karo mengatakan bahwa nasi padi ladang jauh lebih enak dari padi sawah. Selain itu, alasan lain dari penanaman padi ladang adalah untuk mengembalikan daur hidup (life cycle) pertanian setahun sekali yang berjalan sama dengan daur hidup tahunan dari kampungkampung tradisional Karo.” (Elfianto, 2013)

Kebiasan bertanam padi sawah tidak mendukung kultur setempat yang lebih terbiasa mengonsumsi padi ladang. Kondisi ini tentunya menjadi catatan tersendiri bahwa benturan kultural adalah salah satu potret yang akan dijumpai karena pencetakan sawah ibarat proyek 'padinisasi' Indonesia, seperti halnya menjadikan beras sebagai satu-satunya bahan makanan pokok untuk dikonsumsi. Hal ini juga yang dijumpai dalam penelitian Retno (1997) mengenai introduksi teknologi pertanian sawah pada masyarakat Dani di Papua. Dalam proses introduksi, kepala suku menentang sawah karena menganggap padi bukanlah adat yang berasal dari leluhur. Mereka khawatir akan hubungan yang dapat terganggu bila padi dikembangkan. Konsep kerja tradisional bagi masyarakat Dani adalah bertani yang identik dengan mengelola kebun ubi jalar. Padi merupakan tanaman yang berbeda sama sekali dalam pengolahan dan teknologinya yang dinilai lebih tinggi dan sulit serta memengaruhi pembagian kerja tradisional. Dalam masyarakat Dani, wanitalah yang bertanggung jawab untuk menanam, merawat, memanen, dan kemudian menjualnya ke pasar. Teknologi persawahan menyebabkan perubahan pembagian kerja yang ada karena laki-laki harus turun ke sawah mengolah lahan.

\section{CETAK SAWAH, MOBILISASI TRANSMIGRAN DAN ASIMILASI ETNIS}

"Mudah-mudahan..pencanangan cetak sawah baru di Singkawang ini dapat meningkatkan taraf hidup para petani.. Selain itu juga...diharapkan dapat mempererat kerukunan antaretnis/sukusuku yang ada di Singkawang...dan juga mudahmudahan dapat menjadi contoh bagi etnis/suku lainnya yang ada di Singkawang pada khususnya dan yang ada di Indonesia pada umumnya..." (Kalimantan Barat, 1 Juli, 2009).
Kutipan di atas diambil dari catatan pelaksanaan kebijakan cetak sawah baru yang dilakukan di Kabupaten Singkawang, Kalimantan Barat. Kerja sama pencetakan sawah baru dengan luas sekitar 100 hektare di Dusun Kulor, Desa Pajintan, Kecamatan Singkawang Timur, Kota Singkawang dilakukan secara bersama-sama oleh etnis Jawa dan etnis Dayak. Tradisi bersawah yang tidak selalu menjadi kultur yang diakrabi masyarakat setempat, pada akhirnya menempatkan kebijakan pencetakan sawah baru dilakukan di lokasi-lokasi transmigran dan dipersiapkan untuk mendatangkan transmigran baru.

Seperti halnya di Singkawang, pencetakan sawah baru yang dilakukan di Kabupaten Kutai Kalimantan Timur juga memberikan peluang interaksi antara etnis lokal dan etnis Jawa (transmigran). Hal ini dimungkinkan karena sawah-sawah baru yang sudah disiapkan oleh pemerintah ternyata terlantar dan tidak digarap. Salah satu alasan yang menyebabkan tidak digarapnya lahan cetak sawah baru adalah perbedaan tradisi bersawah bagi masyarakat lokal (Kutai) memerlukan pendekatan yang lebih intensif terkait dengan pembekalan keterampilan bersawah. Dalam konteks perbedaan tradisi inilah, solusi yang mungkin dilakukan adalah kerjasama antara etnis lokal dan transmigran. Kelompok lokal akan bekerja berdampingan bersama dengan transmigran dari Jawa (Pujiriyani dkk., 2015).

Kebijakan pencetakan sawah baru yang dilakukan sebagian besar di luar Pulau Jawa memang pada akhirnya dilekatkan kembali dengan program transmigrasi. Fakta sebagian besar sumber daya lahan yang tersedia untuk pencetakan sawah baru berada di luar Pulau Jawa, terutama di Kalimantan dan Papua, membutuhkan penyiapan sumber daya manusia untuk menjadi petani-petani pengolah di lahan cetak sawah baru. Di wilayah tersebut, sumber daya lahan tersedia masih sangat banyak sementara jumlah penduduknya sedikit.

Kultur atau budaya bersawah menunjukkan bahwa sawah merupakan bagian penting dari budaya Indonesia, terutama budaya Jawa dan Sunda. Sebagian besar sawah terbaik yang ada di Pulau Jawa bahkan dibuat secara tradisional dan bertahap sejak ribuan tahun lalu. Petani di Jawa cenderung menjadikan lahannya sebagai 
lahan sawah asalkan air cukup tersedia. Petani transmigran yang berasal dari Pulau Jawa juga mencetak sawah pada lembah-lembah yang cukup airnya. Hal ini memungkinkan orang Jawa lebih terbiasa dengan tradisi bersawah.

Proses asimilasi etnis antara Jawa dan nonJawa untuk pengelolaan sawah baru merupakan sebuah peluang mempertemukan dua etnis yang berbeda. Jika memang pencetakan sawah harus ada, memang seharusnya tidak menghilangkan tradisi bertani tradisional masyarakat lokal. Jika harus bersawah, kedua etnis ini dapat mengenal dan menyatu satu sama lain melalui budaya persawahan. Jika di Papua, sawah yang digarap oleh petani transmigran dianggap lebih memuaskan dibandingkan dengan sawah yang digarap oleh etnis Papua, tentu ini menjadi sangat dimaklumi karena memang basis pertanian etnis Papua adalah pertanian lahan kering dengan pola perladangan berpindah. Contoh serupa juga ditemukan di Provinsi Riau karena etnis Melayu Riau tidak mudah menerima sistem persawahan.

\section{POLARISASI ETNIS DAN POTENSI KONFLIK}

Sebagaimana disebutkan Ananta dkk. (2015, h.125), Jawa merupakan kelompok etnis terbesar yang bisa dijumpai hampir semua provinsi (ubiquity) dengan jumlah 1,5\% populasi di setiap provinsi. Jumlah orang Jawa terbesar dijumpai di beberapa provinsi, seperti Yogyakarta, Jawa Tengah, Jawa Timur, Jakarta, Sumatra Selatan, Lampung, Kalimantan Timur, dan Papua Barat. Sementara itu, orang Jawa juga menempati jumlah terbesar di urutan kedua pada beberapa provinsi, seperti Aceh, Sumatra Utara, Riau, Jambi, Bengkulu, Kepulauan Riau, Jawa Barat, Kalimantan Tengah, Kalimantan Selatan, dan Gorontalo, serta memiliki jumlah terbesar ketiga di beberapa provinsi, seperti Sumatra Barat, Bangka Belitung, Banten, Kalimantan Barat, Sulawesi Tengah dan Papua. Dengan kata lain, Jawa menjadi kelompok etnis migran terpenting di 29 provinsi di Indonesia. Pengalaman transmigrasi yang telah dimulai pada periode kolonial dengan pengiriman sejumlah besar etnis Jawa ke berbagai pulau di luar Jawa merupakan bagian dari proses yang disebut Arndt (1983, hlm.64) sebagai 'Javanisasi'. Keberadaan etnis Jawa di berbagai tempat ini menjadi bagian penting yang juga harus dilihat.

Papua Barat termasuk provinsi atau wilayah yang sangat heterogen. Di Papua Barat, orang Jawa merupakan kelompok etnis migran yang paling besar yaitu sejumlah $14,7 \%$ atau 111.181 penduduk dari total 753.399 jumlah penduduk. ${ }^{1}$ Di Papua Barat ini terdapat etnis Arfak yang merupakan kelompok etnis asli Papua Barat yang terbesar dengan jumlah populasi $9,18 \%$ atau 69.182 penduduk, diikuti Biak-Numfor $7,47 \%$ atau 56.269 penduduk, serta Afyat 6,06\% atau 45.687 penduduk. Selain keempat etniks dengan jumlah yang cukup besar ini, terdapat 22 etnis yang lain yang ada di Papua Barat. Etnisetnis lain ini diantaranya: Buginese, Ambonese, Butonese, Baham, Yapen, Mooi, Makassarese, Kei/Evav, Tehit, Toraja, Minahasa, Wandamen, Irahutu, Kokoda, Seram, Inanwatan, Wamesa, Flores, Sundanese, Batak, Ternate.

Selain Papua Barat, Papua merupakan provinsi yang disebut almost heterogenous. Papua memliki variasi kelompok etnis paling besar, dengan jumlah terbesar berasal dari kelompok etnis lokal. Delapan dari 25 kelompok etnis terbesar merupakan kelompok etnis migran. Kecuali migran yang berasal dari Jawa, Ambon, dan Kei, semua migran berasal dari Pulau Sulawesi (Bugis, Buton, Makasar, Minahasa, dan Toraja). Di Papua, masyarakat Dani merupakan kelompok etnis lokal terbesar dengan jumlah 23,32\% atau 648.227 penduduk. Kelompok etnis terbesar kedua adalah Auwye/Mee dengan jumlah 11,32\% atau 314,582 penduduk. Kelompok ketiga adalah etnis migran yaitu orang Jawa dengan jumlah $8,38 \%$ atau 232.940 penduduk. Papua memiliki jumlah populasi terkecil yaitu 0,7 juta populasi. Populasi di Papua Barat juga menghadapi lebih banyak tantangan dibandingkan mereka yang tinggal di Pulau Jawa karena secara geografis kondisi Papua Barat juga pembangunan infrastrukturnya termasuk lambat.

Dengan karakteristiknya sebagai provinsi yang heterogenous dan almost heterogenous,

\footnotetext{
1 Jawa merupakan kelompok etnis terbesar di Indonesia dengan jumlah keseluruhan 40,06 \% dari total populasi yang hidup di Indonesia (Ananta dkk., 2015, h.77).
} 
Papua Barat dan Papua harus bersiap menerima gelombang transmigran baru. Ditambahkan Mampioper (2008), pertumbuhan penduduk di Papua bertambah karena perpindahan penduduk secara spontan atau pun diatur oleh pemerintah Indonesia melalui program transmigrasi. Jika menyimak populasi penduduk di Papua sejak tahun 1960 sesuai data Netherlands Government Annual Report to the United Nations on Netherlands New Guinea 1960, jumlah penduduk asli Papua 736.700 jiwa yang didominasi oleh penduduk asli Papua. Berdasarkan Sensus Penduduk tahun 1971, jumlah penduduk Papua bertambah sekitar 200 ribu orang menjadi 923.440 orang. Kenaikan jumlah penduduk selama sepuluh tahun ini relatif lebih tinggi jika dibandingkan dengan zaman pemerintahan Nederlands Nieuw Guinea. Pakar kependudukan Papua dari PSK Uncen almarhum Drs. Michael Rumbiak, MA mengemukakan bahwa setelah Pepera tahun 1969 pemerintah Indonesia menyatakan Provinsi Papua terbuka (open door policy) bagi orang Indonesia. Hal ini membuat orang Indonesia dari luar Papua bebas masuk Papua untuk berusaha dan mencari pekerjaan baik di sektor swasta maupun pemerintahan. Sejak tahun 1970-an sampai dengan tahun 2000, jumlah penduduk di Tanah Papua meningkat sangat cepat dan tajam tiga kali lipat dari 700.000 orang menjadi 2,5 juta orang. Dari jumlah 2,5 juta jiwa tersebut, orang asli Papua diperkirakan hanya mencapai jumlah sekitar 1,5 juta orang atay terjadi penambahan 800.000 jiwa orang asli Papua. Sebanyak 17\% penduduk Papua saat ini merupakan warga transmigrasi. Hal ini belum termasuk anak dan keturunannya. Malah kemungkinan jumlah penduduk transmigran itu akan bertambah. Program transmigrasi seakanakan membatasi orang Papua tetap sedikit (minoritas) di tanah kelahirannya atau tanah leluhur mereka. Kenyataannya, orang Papua bertambah sangat lambat dan tidak mengimbangi orangorang non Papua di daerah transmigrasi dan membuat mereka menjadi minoritas.

Mengulang sejarah transmigrasi, pencetakan sawah baru menjadi penanda gelombang transmigran ke tanah Papua. Pencetakan sawah baru yang direalisasikan melalui MIFEE membutuhkan sekitar 4,8 juta tenaga kerja baru yang diperkirakan 4 orang untuk setiap hektarenya
(Omona, 2014). Dalam hal ini, bisa dipastikan bahwa jumlah kelompok etnis lokal akan menjadi semakin minoritas. Masuknya migran dalam jumlah besar dalam skema MIFEE memiliki pengaruh signifikan. Berikut ini adalah gambaran yang ditunjukkan mengenai orang Marind di tengah kehadiran para pendatang:

"Ketika gelombang pendatang masuk ke Merauke. Kebanyakan pendatang adalah orang Jawa yang dibawa Belanda, dan di Merauke kini mereka dikenal dengan sebutan Jamer (Jawa Merauke). Pertemuan itu membuat orang Marind-yang umumnya berpostur tegap tinggi besar dan hidung mancung--mulai kenal pertanian padi dan palawija. Lahan persawahan pun mulai dibuka di sekitar pantai Merauke, dan Distrik Kurik. Saat itulah, sekitar 1910, sejumlah warga Marind membuka sawah dan menanam padi. Perkenalan suku Marind pada sistem pertanian modern berlanjut hingga gelombang transmigrasi tahun 1965 sampai 1995. Pada tahun 1985, pemerintah merelokasi keluarga-keluarga Marind di daerah transmigran, dan membekali dengan pertanian modern, dari mengolah tanah dengan pacul dan traktor, menabur benih, dan memupuk, hingga memanen. Susahnya, sebagian warga tidak memiliki ketekunan dan keuletan bertani. Ini wajar, karena sekian generasi mereka diberkahi kemurahan alam. Karenanya, seperti kata Wakil Ketua Lembaga Masyarakat Adat Marind-anim, Alberth Gebze Moyuend: sebagian warga meninggalkan sawah mereka karena merasa tak sesuai kultur dan adat. Tercatat, lahan sawah yang terbengkalai mencapai 34 persen dari 38.402 ha lahan pertanian di Merauke" (Prasetya \& Harthana, 2011).

Berkembang sebuah stigma bahwa migran mendapatkan gaji atau upah yang lebih baik dibandingkan penduduk lokal. Masyarakat Papua sering kali menyebut hal ini sebagai genosida terhadap tanah mereka. Genosida ini juga diartikan dalam konteks kultural dengan pelenyapan identitas, kosmologi, dan pola-pola kehidupan mereka. Orang-orang Marind memahami bahwa mereka adalah bagian dari lanskap dengan setiap klan yang bertanggung jawab pada setiap tumbuhan dan hewan yang hidup di dalamnya. Jika subsistensi diartikan harus berebut dengan para pendatang ini, apakah kemudian semua orang Marind dapat mendapatkan pekerjaan atau mereka harus pergi ke kota-kota dan mendapat stigmatisasi dari kelompok pendatang yang akan 
berpengaruh terhadap kepercayaan diri dan prospek pekerjaan mereka.

Migran ke Papua datang dalam sebuah lingkungan yang dipenuhi asumsi rasisme yang tersebar luas. Etnis asli Papua seringkali menjadi subjek dari dislokasi kehidupan tradisionalitas mereka yang pada akhirnya membuat mereka tidak menemukan atau memiliki motivasi untuk menyesuaikan diri menjadi seorang petani padi yang sukses. Ketika mereka ke kota, mereka jarang sekali sukses dalam berbisnis. Rasionalisasi rasis menstigmakan orang Papua sebagai 'orang yang malas, pemabuk, tidak disiplin dan kurang terpelajar'. Diskriminasi yang dihadapi oleh orang Papua di tanahnya sendiri inilah yang menjadi legitimasi bagi kelompok migran baru untuk mendominasi wilayah-wilayah yang mereka datangi.

Polarisasi etnis terjadi dengan menguatnya identitas antara Jawa dan non-Jawa (Papua) dengan stigma masing-masing. Kondisi serupa inilah yang perlu dipahami dan disadari sepenuhnya akan sangat rentan menciptakan konflik. Kondisi keberagaman etnis di Indonesia dalam konteks pencetakan sawah baru harus dilihat secara hati-hati karena desain kebijakan ini sangat kompleks. Mencetak sawah tidak sekedar mengubah lanskap, tetapi juga mengubah situasi sosio-kultural masyarakat. Introduksi teknologi dalam wujud pencetakan sawah baru seharusnya tidak dimaknai sebagai homogenisasi atau genosida kultural. Jangan sampai yang terjadi kemudian mencetak sawah baru justru lebih tepat disebut mencetak masalah baru atau bahkan memindahkan masalah krisis pangan menjadi masalah konflik etnis.

\section{KETERSEDIAAN PETANI DI LAHAN SAWAH BARU DAN PROBLEM PENUAAN POPULASI}

Selain persinggungan etnis, pencetakan sawah baru menghadirkan persoalan terkait dengan ketersediaan petani berusia muda yang akan mengolah lahan-lahan sawah baru. Hal ini kembali menekankan kondisi Indonesia yang menghadapi persoalan krisis regenerasi petani. Sebagaimana disinggung oleh Anwarudin dkk. (2020), regenerasi pelaku pertanian di
Indonesia berjalan lambat dan relatif rendah. Hasil Sensus Pertanian tahun 2013 menunjukan bahwa sebagian besar petani di Indonesia berusia lanjut. Porsi petani berdasarkan kelompok umur terdiri dari usia di atas 54 tahun, 35-54 tahun, dan kurang dari 35 tahun, secara berturut-turut adalah $32,76 \%, 54,37 \%$, dan $12,8 \%$. Situasi ini menunjukkan bahwa pada kenyataannya tenaga kerja pertanian di Indonesia lebih banyak diisi oleh petani berusia lanjut.

Dominannya petani berusia lanjut akan menjadi persoalan karena keberadaan sawahsawah baru tentunya harus didukung dengan sumber daya manusia yang memadai. Petani berusia lanjut dikhawatirkan tidak akan mampu mendukung optimalisasi target dari sawah baru untuk menjadi pilar ketahanan pangan di Indonesia. Sebagaimana dicatat oleh Ananta dkk. (2015), setiap kelompok etnis di Indonesia pada dasarnya akan mengalami perubahan struktur usia (the changing age structure). Perubahan struktur usia ini dibedakan dalam lima kategori yaitu: (i) kategori very young yaitu ketika jumlah penduduk usia tua di bawah 6\%; (ii) kategori youthful yaitu ketika jumlah penduduk usia tua antara 6-8\%; (iii) kategori transitional yaitu ketika jumlah penduduk usia tua antara $8-12 \%$; (iv) kategori old yaitu ketika jumlah penduduk usia tua di atas 12\%; dan (v) kategori super-old yaitu ketika jumlah penduduk usia tua lebih dari 20\%. Dalam kecenderungan mega demografi di Indonesia, terdapat tiga kelompok etnis yang memasuki fase transitional, yaitu etnis Jawa, etnis Madura, dan etnis Bali.

Dalam konteks pencetakan sawah baru, kasus sebelumnya menunjukkan bahwa Jawa merupakan etnis dominan yang didatangkan untuk mengisi kebutuhan tenaga kerja di lokasi-lokasi cetak sawah. Etnis Jawa juga bisa dikatakan identik dengan transmigran yang ada di lokasi cetak sawah baru. Ketika yang terjadi adalah kecenderungan transisi menuju old population, harus disiapkan kebijakan lain untuk bisa memenuhi kebutuhan tenaga kerja di lokasi-lokasi cetak sawah. Hal ini pun berlaku juga jika petani atau tenaga tersebut berasal dari etnis Madura dan etnis Bali. Hal ini kembali menegaskan bahwa kebijakan pencetakan sawah baru perlu menyiap- 
kan infrastruktur pertanian yang tidak melupakan pentingnya ketersediaan sumber daya manusia atau ketersediaan petaninya. Sawah merupakan pertanian intensif yang membutuhkan banyak tenaga kerja pertanian. Semakin luas sawah, berarti semakin banyak tenaga kerja atau petani yang dibutuhkan.

Jika petani untuk lahan-lahan sawah baru tidak tersedia, dikhawatirkan sawah tidak akan bisa dikelola dengan baik. Mekanisasi pertanian dalam hal ini sangat diperlukan. Meskipun demikian, perlu diperhatikan bahwa cetak sawah baru membawa potensi persoalan konflik etnis yang sangat riskan. Penyiapan infrastruktur tanpa memperhatikan kerentanan sosial serupa ini akan sangat tidak menguntungkan bagi keberlanjutan kebijakan ini di masa mendatang.

\section{KESIMPULAN}

Pencetakan sawah baru disebutkan telah berhasil meningkatkan perekonomian masyarakat. Melalui pencetakan sawah, masyarakat memiliki peluang untuk bisa mengubah lahan-lahan yang semula tidak produktif menjadi lahan produktif yang memberikan peningkatan pendapatan. Implementasi kebijakan pencetakan sawah baru berimplikasi pada dua hal yaitu (i) menciptakan peluang asimilasi melalui kerjasama antara etnis pendatang (transmigran) dengan etnis lokal dalam mengerjakan atau mengolah lahan cetak sawah baru; dan (ii) gelombang transmigran yang didatangkan ke lokasi-lokasi cetak sawah baru memicu terjadinya polarisasi etnis yang rentan menimbulkan benih-benih konflik etnis. Kondisi ini dimungkinkan karena komposisi etnis di setiap lokasi cetak sawah sebagian besar didominasi oleh kelompok transmigran dari etnis Jawa.

Potensi persoalan ke depan yang akan dihadapi ketika lahan-lahan cetak sawah sudah tersedia adalah prediksi akan terjadinya tren mega demografi yaitu penuaan populasi (ageing population) akibat fertilitas yang relatif rendah. Terdapat beberapa kelompok etnis di Indonesia yang diperkirakan akan paling cepat mengalami penuaan populasi yaitu: Jawa, Madura, dan Bali. Masyarakat Jawa misalnya diperkirakan akan mengalami penurunan persentase jumlah orang muda dan meningkatnya jumlah orang tua.
Kondisi ini akan menjadi pemikiran serius karena penuaan populasi menandakan berkurangnya tenaga produktif yang berarti jikalau sawahsawah tersebut akan ada, pada akhirnya kembali akan dikelola oleh generasi-generasi tua, karena realitas saat ini desa dan persawahan sudah tidak menarik bagi anak muda. Pengelolaan sawah oleh generasi tua ini dikhawatirkan tidak akan mampu meningkatkan produktifitas pertanian dan kembali lagi sawah-sawah akan terlantar atau bahkan mungkin dijual.

Pencetakan sawah baru sudah seharusnya mempertimbangkan aspek sosial budaya, termasuk persoalan etnis dan kesesuaian budaya. Kebijakan sawah baru tidak bisa hanya diposisikan sebagai akselerasi infrastruktur pertanian tanpa mempertimbangkan bahwa sawah berkaitan erat dengan 'budaya menanam padi di lahan basah'. Bercocok tanam padi di sawah bukan budaya yang dikenal oleh semua kelompok etnis di Indonesia. Jika yang kemudian dianggap cocok untuk menjadi pengelola sawah-sawah baru adalah etnis tertentu yang harus didatangkan melalui skema transmigrasi ataupun mobilisasi lain, yang akhirnya menghadirkan kantong-kantong pendatang, maka persinggunggan etnis yang rentan memicu konflik dengan penduduk atau komunitas lokal setempat harus terlebih dahulu dipertimbangkan.

\section{DAFTAR PUSTAKA}

Alesina, A., \& La Ferrara, E. (2005). Ethnic diversity and economic performance. Journal of Economic Literature, 43(3), 762-800. https://doi. org/10.1257/002205105774431243

Ananta, A., Arifin, E. N., Hasbullah, M. S., Handayani, N. B., \& Pramono, A. (2015). Demography of Indonesia's ethnicity. ISEAS Publishing. https://doi.org/10.1355/9789814519885

Anwarudin, O., Sumardjo, Satria, A., \& Fatchiya, A. (2020). Proses dan pendekatan regenerasi petani melalui multistrategi di Indonesia. Jurnal Penelitian dan Pengembangan Pertanian, 39, 73-85. https://doi.org/10.21082/jp3. v39n2.2020.p73-85

Arndt, H. W. (1983). Transmigration: Achievements, problems, prospects. Bulletin of Indonesian Economic Studies, 19(3), 50-73. https://doi. org/10.1080/00074918312331334429

Astuti, N.B., \& Kurniawan, B. (2017, Oktober). Analisis pemanfataan program pencetakan 
sawah baru (Kasus di Nagari Siguhung, Kecamatan Lubuk Basung, Kabupaten Agam, Sumatera Barat). Prosiding Seminar Nasional Lahan Suboptimal 2017, Universitas Sriwajaya, Palembang.

Darwis, V. (2019). Evaluasi pelaksanaan cetak sawah di Provinsi Kalimantan Barat. Jurnal Penelitian Pertanian Terapan, 19(2), 160-168. https://doi. org/10.25181/jppt.v19i2.1569

Elfianto, Z. (2013). Cetak sawah Indonesia. Direktorat Perluasan dan Pengelolaan Lahan Direktorat Jenderal Prasarana dan Sarana Pertanian Kementrian Pertanian.

Esteban, J., \& Ray, D. (1994). On the measurement of polarization. Econometrica, 62(4), 819-851. https://doi.org/10.2307/2951734

Haryanti, R. (2020, 24 Juni). "Food estate" dan kilas balik proyek lahan gambut sejuta hektar. Kompas.com. https://properti.kompas.com/ $\mathrm{read} / 2020 / 06 / 24 / 070000221 /$-food-estatedan-kilas-balik-proyek-lahan-gambut-sejutahektar?page $=$ all

Husain, N. (2018). Persepsi masyarakat terhadap program cetak sawah baru (Kasus di Desa Marente Kecamatan Alas Kabupaten Sumbawa [Skripsi Sarjana, Universitas Mataram]. Universitas Mataram Repository. http://eprints. unram.ac.id/4354/

Ikwanto, A., Yusuf, Halkis, H.M. (2019). Evaluasi program cetak sawah oleh Korem 174/ATW di Merauke dalam mendukung ketahanan pangan nasional. Jurnal Strategi Perang Semesta, 5(2), 41-56. http://jurnalprodi.idu.ac.id/index.php/ SPS/article/view/430/0

Larastiti, C. (2018). Sonor dan bias ‘cetak sawah’ di lahan gambut. Bhumi, 4(1), 67-87. https://doi. org/10.31292/jb.v4i1.216

Mampioper, D. A. (2008, 21 Juli). Dari kolonisasi sampai transmigrasi di tanah Papua. kabarindonesia.com. http://www.kabarindonesia.com/ berita.php?pil $=20 \& d n=20080721134337$

Mawardi, B.. (2015, 8 Maret). Imajinasi sawah masa lalu. Sindonews.com. https://nasional. sindonews.com/berita/973563/149/imajinasisawah-masa-lalu/10

Miranda, R. J., \& Adventa, A. (2020, 10 Juli). Cetak sawah baru di Kalteng, babak baru bencana ekologi? Mongabay. https://www.mongabay. co.id/2020/07/10/cetak-sawah-baru-di-kaltengbabak-baru-bencana-ekologi/

Mustapa, L. A., Purnamadewi, Y. L., \& Dharmawan, A. H. (2019). Dampak dan keberlanjutan program cetak sawah di Kabupaten Katingan, Provinsi Kalimantan Tengah. Analisis Kebi- jakan Pertanian, 17(2), 123-137. https://doi. org/10.21082/akp.v17n2.2019.123-137

Mustikarini, E. D., \& Santi, R. (2020). Strategi pemberdayaan petani lahan cetak sawah baru melalui LEISA. Society, 8(1), 25-38. https:// doi.org/10.33019/society.v8i1.143

Nugraha, I. (2016, 10 Juni). Lahan gambut eks PLG satu juta ha, bagaimana kabarnya saat ini? Mongabay. https://www.mongabay. co.id/2016/06/10/lahan-gambut-eks-plg-satujuta-hektar-bagaimana-kabarnya-saat-ini/

Nurhana, Rukka, R. M., Sari, P. D., Rukmana, D., Bulkis, S., \& Bakri, R. (2019). Analisis aspek sosial ekonomi petani padi peserta program pencetakan sawah baru. Jurnal Sosial Ekonomi Pertanian, 15(1), 17-30. https://doi. org/10.20956/jsep.v15i1.6256

Omona, J. (2014, 20 Desember). Suku Marind, bergelut dengan modernisasi. Jerat Papua. https:// www.jeratpapua.org/2014/12/20/suku-marindbergelut-dengan-modernisasi/

Prasetyo, B. H. (2006). Evaluasi tanah sawah bukaan baru di daerah Lubuk Linggau, Sumatera Selatan. Jurnal Ilmu-Ilmu Pertanian Indonesia, 8(1), 31-43. https://ejournal.unib.ac.id/index. $\mathrm{php} / \mathrm{JIPI} /$ article/view/4749

Prasetya, E. E., \& Harthana, T. (2011, 16 April). Suku Marind, di antara busur dan pacul. Kompas.com. https://ekonomi.kompas.com/ $\mathrm{read} / 2011 / 04 / 16 / 09204571 / \mathrm{suku}$.marind. di.antara.busur.dan.pacul?page $=$ all

Pujiriyani, D. W., Puri, W. H., \& Salim, M. N. (2015). Kebijakan penyediaan lahan mendukung ketahanan pangan di Kabupaten Kutai Kertanegara, Provinsi Kalimantan Timur. Sekolah Tinggi Pertanahan Nasional. http://repository.stpn. ac.id/811/

Putri, C. A. (2020, 16 Juni). Ancaman krisis pangan 1,4 juta ha gambut disulap jadi sawah. $C N B C$ Indonesia. https://www.cnbcindonesia.com/ news/20200616202533-4-165880/ancamankrisis-pangan-14-juta-ha-gambut-disulap-jadisawah

Ramadani, F., Setiowati, \& Luthfi, A. N. (2019). Pencetakan sawah baru dan penguatan aset tanah petani untuk ketahanan pangan (Studi Desa Masta Kec. Bakarangan Kab. Tapin, Prov. Kalimantan Selatan). Jurnal Tunas Agraria, 2(1), 95-112. https://doi.org/10.31292/jta. v2i1.19

Retno, S. D. W. I. K. (1997). Peranan teknologi pertanian - sawah terhadap perubahan organisasi sosial (Studi kasus masyarakat Desa Tulem, Kecamatan Kurulu, Kabupaten 
Jayawijaya-Irian Jaya) [Disertasi Doktoral, Institut Pertanian Bogor]. IPB University Scientific Repository. https://repository.ipb. ac.id/handle/123456789/830

Sastrawan, R., Barcia, F., \& Uker, D. (2019). Persepsi masyarakat terhadap program percetakan sawah baru di Desa Air Kering Kecamatan Padang Guci Hilir Kabupaten Kaur dan pengaruhnya terhadap lingkungan. NaturalisJurnal Penelitian Pengelolaan Sumberdaya Alam dan Lingkungan, 8(1), 99-111. https:// doi.org/10.31186/naturalis.8.1.9171

Snyder, H. (2019). Literature review as a research methodology: An overview and guidelines. Journal of Business Research, 104, 333-339. https://doi.org/10.1016/j.jbusres.2019.07.039
Suandi, Siata, R., \& Sardi, I. (2013). Sikap petani terhadap program pencetakan sawah baru di Kelurahan Simpang Kecamatan Berbak Kabupaten Tanjung Jabung Timur. Sosio Ekonomika Bisnis, 16(2), 45-52. https://doi.org/10.22437/ jiseb.v16i2.2779

Thoriq, A., \& Sampurna, R. M. (2016). Evaluasi potensi pengairan calon lokasi perluasan sawah di Kabupaten Tulang Bawang, Provinsi Lampung. Jurnal Teknik Pertanian Lampung, 5(3), 185-190. https://jurnal.fp.unila.ac.id/ index.php/JTP/article/view/1322

Tim Analisis BPK Biro Analisa APBN \& Sugema, I. (2013). Catatan kritis atas hasil pemeriksaan BPK pada kegiatan perluasan (pencetakan) sawah dalam program peningkatan ketahanan pangan tahun anggaran 2007-2009. https:// adoc.pub/queue/oleh-tim-analisa-bpk-biroanalisa-apbn-iman-sugema.html 